\title{
Effect of arsenic stress on 5-methylcytosine, photosynthetic parameters and nutrient content in arsenic hyperaccumulator Pteris cretica (L.) var. Albo-lineata
}

Veronika Zemanová ${ }^{1,2}$, Marek Popov $^{3}$, Daniela Pavlíkováa ${ }^{2}$ Pavel Kotrba ${ }^{3}$, František Hnilička ${ }^{4}$, Jana Česká ${ }^{4}$ and Milan Pavlík ${ }^{1 *}$

\begin{abstract}
Background: Arsenic toxicity induces a range of metabolic responses in plants, including DNA methylation. The focus of this paper was on the relationship between As-induced stress and plant senescence in the hyperaccumulator Pteris cretica var. Albo-lineata (PC-Al). We assume difference in physiological parameters and level of DNA methylation in young and old fronds as symptoms of As toxicity.

Results: The As accumulation of PC-Al fronds, grown in pots of haplic chernozem contaminated with $100 \mathrm{mg} \mathrm{As} \mathrm{kg}^{-1}$ for 122 days, decreased with age. Content of As was higher in young than old fronds for variants with $100 \mathrm{mg} \mathrm{As} \mathrm{kg}^{-1}$ (2800 and $2000 \mathrm{mg} \mathrm{As} \mathrm{kg}^{-1}$ dry matter, respectively). The highest As content was determined in old fronds of Pc-Al grown in pots with $250 \mathrm{mg} \mathrm{As} \mathrm{kg}^{-1}$. The increase with age was confirmed for determined nutrients $-\mathrm{Cu}, \mathrm{Mg}, \mathrm{Mn}, \mathrm{S}$ and Zn. A significant elevation of all analysed nutrients was showed in old fronds. Arsenic accumulation affected DNA methylation status in fronds, but content of 5-methylcytosine $(5 \mathrm{mC})$ decreased only in old fronds of Pc-Al (from 25 to 12\%). Determined photosynthetic processes showed a decrease of fluorescence, photosynthetic rate and chlorophylls of As treatments in young and old fronds. Water potential was decreased by As in both fronds. Thinning of the sclerenchymatous inner cortex and a reduction in average tracheid metaxylem in the vascular cylinder was showed in roots of As treatment. Irrespective to fronds age, physiological parameters positively correlated with a $5 \mathrm{mC}$ while negatively with direct As toxicity. Opposite results were found for contents of $\mathrm{Cu}, \mathrm{Mg}, \mathrm{Mn}, \mathrm{S}$ and $\mathrm{Zn}$.

Conclusions: The results of this paper point to changes in the metabolism of the hyperaccumulator plant $P$ c-Al, upon low and high exposure to As contamination. The significant impact of As on DNA methylation was found in old fronds. Irrespective to fronds age, significant correlations were confirmed for $5 \mathrm{mC}$ and As toxicity. Our analysis of the very low water potential values and lignification of cell walls in roots showed that transports of assimilated metabolites and water between roots and fronds were reduced. As was showed by our results, epigenetic changes could affect studied parameters of the As hyperaccumulator plant Pc-Al, especially in old fronds.
\end{abstract}

Keywords: Pteridaceae, Long-term stress, Toxic element, Epigenetic change, DNA demethylation

\footnotetext{
* Correspondence: pavlik@biomed.cas.cz

${ }^{1}$ Isotope Laboratory, Institute of Experimental Botany, The Czech Academy of Sciences, Vídeňská 1083, 14220 Prague, Czech Republic

Full list of author information is available at the end of the article
}

(c) The Author(s). 2020 Open Access This article is licensed under a Creative Commons Attribution 4.0 International License, which permits use, sharing, adaptation, distribution and reproduction in any medium or format, as long as you give appropriate credit to the original author(s) and the source, provide a link to the Creative Commons licence, and indicate if changes were made. The images or other third party material in this article are included in the article's Creative Commons licence, unless indicated otherwise in a credit line to the material. If material is not included in the article's Creative Commons licence and your intended use is not permitted by statutory regulation or exceeds the permitted use, you will need to obtain permission directly from the copyright holder. To view a copy of this licence, visit http://creativecommons.org/licenses/by/4.0/ The Creative Commons Public Domain Dedication waiver (http://creativecommons.org/publicdomain/zero/1.0/) applies to the data made available in this article, unless otherwise stated in a credit line to the data. 


\section{Background}

Environmental pollution with arsenic (As) poses a risk to plant, animal and human health. Uptake and accumulation of this element by plants vary according to plant species. For most plants, significantly reduced growth and fitness is evident at soil arsenic concentrations of $25.0-85.0 \mathrm{mg} \mathrm{kg}^{-1}$ total As [1]. In contrast, some fern species of the Pteridaceae family can tolerate As and accumulate it in their above-ground tissues to $>1000 \mathrm{mg} \mathrm{As} \mathrm{kg}^{-1}$ dry weight [2, 3]. The cultivars of Pteris cretica (var. Albo-lineata, Wimsetti and Alexandrae) were identified as an arsenic hyperaccumulators by Zhao et al. [3], who reported that this species accumulates As to the levels found in $P$. vittata, the first As-hyperaccumulating species identified. Arsenate $\left(\mathrm{As}^{\mathrm{V}}\right)$ taken up by roots of $P$. vittata from the soil was reduced to arsenite $\left(\mathrm{As}^{\mathrm{III}}\right)$, which was rapidly transported to the vacuoles of the upper and lower epidermal cells and trichomes of the fronds [4]. Tu and Ma [5] found that As in the fronds of $P$. vittata was primarily contained as inorganic arsenite (average of 94\%). According to these authors arsenite re-oxidation to arsenate occurred more often with senescence of fronds. Koller et al. [6] confirmed the effect of the development stage of fronds of Pteris umbrosa on As content. The senesced fronds had a significantly lower As content in contrast to green fronds while expanding fronds had the highest As content. The different result increase in As concentration from young to mature and old fronds was shown in P. vittata [5].

Arsenic stress can provoke numerous toxic effects in plants. As is widely reported to inhibit the rate of photosynthesis in plants and to reduce chlorophyll concentration [7]. Agnihotri and Seth [8] showed a decline in photosynthetic pigments and gaseous exchange parameters in plants exposed to As, indicating the onset of senescence. Foyer and Noctor [9] also confirmed that oxidative stress activates senescence associated with the degradation of photosynthetic pigments and remobilises the basic nutrients C, N, P, and S. Modified stress metabolism due to extended reversible senescence releases nutrients from catabolic processes and transports them from old leaves into young leaves more efficiently.

Studies have also revealed that stress-inducing abiotic factors, including As, can trigger epigenetic changes (in particular DNA methylation/demethylation), which may contribute to the regulation of gene expression in chronic stress conditions [10]. Phenotypic manifestations of epigenetic changes include reduced plant growth (dwarfism) and development (in particular seed germination [11]), flowering period [12, 13] and male fertility/ sterility of anthers and/or pollens [14].

The primary detoxification of As in the cells of terrestrial plants relies on rapid reduction of $\mathrm{As}^{\mathrm{V}}$ to $\mathrm{As}{ }^{\mathrm{III}}$ and the formation of $\mathrm{As}^{\mathrm{III}}$-glutathione or $\mathrm{As}^{\mathrm{III}}$-phytochelatin complexes, which are eventually transported to the vacuole.
Disturbances in cellular processes, caused by a toxic excess of As, induce oxidative stress responses [15-17], methylation of both As forms in P. cretica [18], and epigenetic changes in DNA [19]. In this study, we aimed to gain insight into the context of As hyperaccumulation and plant senescence in Pteris cretica var. Albo-lineata. In addition, we examined related changes in selected physiological parameters and DNA methylation status as potentially indicative of epigenetic modification. The degree of senescence was evaluated with respect to different changes found in young and old fronds of $P$. cretica var. Albo-lineata.

\section{Results}

\section{Growth and elemental content of As-exposed $P$. cretica} var. Albo-lineata

The effect of $\mathrm{As}_{100}$ soil was observed only on young fronds. The dry biomass of $\mathrm{Pc}$-Al young fronds was decreased by $43 \%$ (Fig. 1). The effect of $\mathrm{As}_{250}$ soil was not observed. Differences between young and old fronds of $\mathrm{Pc}$-Al were not statistically significant. Symptoms of As toxicity were not observed.

The analysis of the concentration of elements in dried fronds of $P c$-Al revealed that the highest As concentration was determined in $\mathrm{As}_{250}$ old fronds (Table 1). In the control and $\mathrm{As}_{100}$ soil condition, young fronds had approximately 1.5 times higher concentrations of As than old ones (Table 1). Compared with controls, ferns grown in the $\mathrm{As}_{100}$ soils increased As concentrations 150- and 170-fold in young and old fronds, respectively. Ferns grown in the $\mathrm{As}_{250}$ soil increased As concentration 421-fold compared to control. Irrespective of the presence of added As in the soils, old fronds tended to accumulate higher concentrations of $\mathrm{Cu}, \mathrm{Mg}, \mathrm{Mn}, \mathrm{S}$ and $\mathrm{Zn}$ than young fronds (Table 1, Fig. 2). The effect of high soil As - $\mathrm{As}_{100}$ and $\mathrm{As}_{250}$ on the $\mathrm{Cu}$ accumulation showed an increase in young fronds (by 17\%) and old fronds (by 100\%), respectively. The increases in S (59\%) and $\mathrm{Zn}(86 \%)$ concentration were only observed in old fronds. When grown in $\mathrm{As}_{100}$ and $\mathrm{As}_{250}$ soils, the concentrations of $\mathrm{Mg}$ and $\mathrm{Mn}$ increased in old fronds of $\mathrm{Pc}$ $\mathrm{Al}$ (Mg by $60 \%$ and $\mathrm{Mn}$ by $66 \%$ ) but decreased in young fronds (Mg by $6 \%$ and $\mathrm{Mn}$ by $18 \%$ ).

Values with the same letter were not statistically significant at the 0.01 level by the Kruskal-Wallis test. Different letters indicate significantly different values $(p<0.01)$ : $\mathrm{a}, \mathrm{b}$ comparison between the treatments of young fronds (control and $\mathrm{As}_{100}$ ) and old fronds (control, $\mathrm{As}_{100}$ and $\left.\mathrm{As}_{250}\right) ; \mathrm{A}, \mathrm{B}$ comparison between young and old fronds for control and $\mathrm{As}_{100}$ treatment. Results for comparison between control and $\mathrm{As}_{100}$ of young and old fronds are in Additional File 1. Coefficients of variation $(\mathrm{CV}, \%)$ are in Additional File 2. 


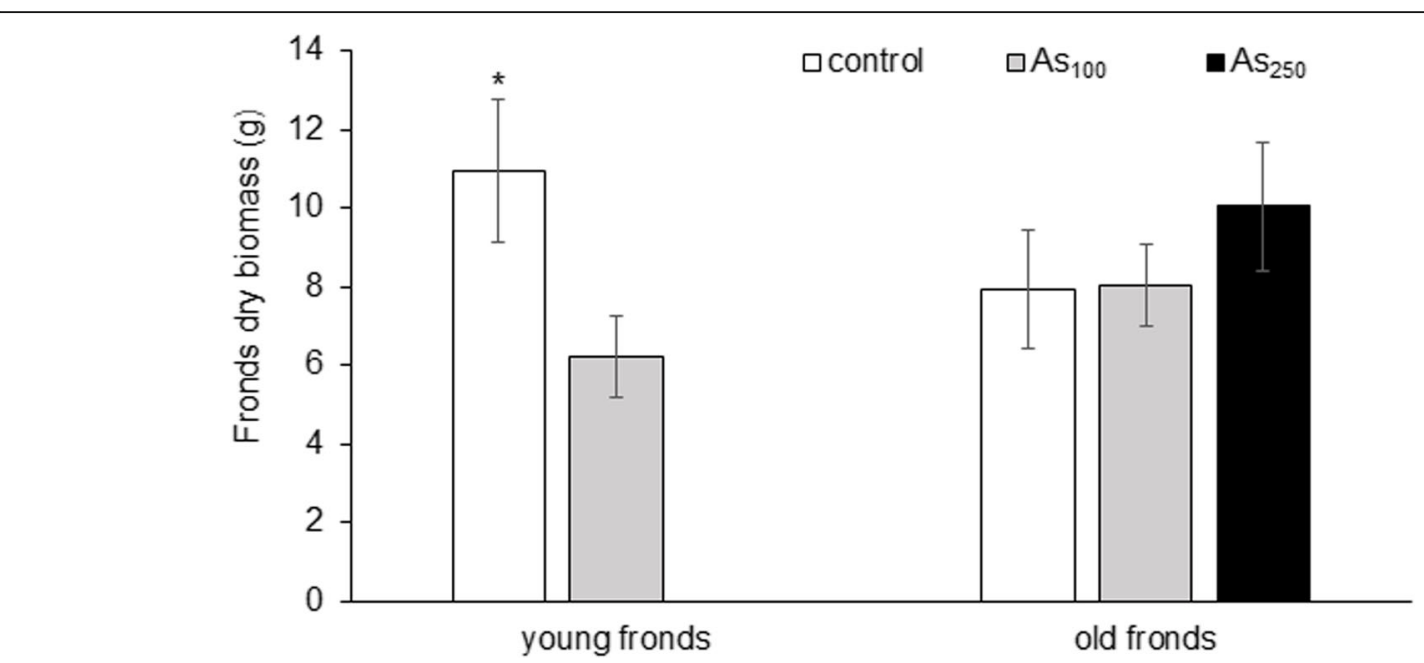

Fig. 1 Dry biomass of young and old fronds of $P$. cretica var. Albo-lineata. Values represent mean \pm SD. The Kruskal-Wallis test was used to compare the significance $(p<0.05)$ between: i) treatments of young fronds (control and $\left.A s_{100}\right)$ and old fronds (control, $A s_{100}$ and $\left.A s_{250}\right)$ and ii) young and old fronds of control and $\mathrm{As}_{100}$ treatment. Treatments significantly different from each other are marked with asterisks. Differences between young and old frond was not significant

DNA methylation status of As-exposed $P$. cretica var.

\section{Albo-lineata}

Since As and senescence might affect the methylation of DNA at cytosines in plants, the 5-methylcytosine content (5mC, \%) of Pc-Al DNA was analysed (Figs. 2 and 3). Compared with controls, the overall DNA methylation status in fronds of ferns grown in $\mathrm{As}_{100}$ soils was fluctuated from 27 to $21 \%$ in young and from 25 to $15 \%$ in old fronds. The $5 \mathrm{mC}$ content in old fronds of ferns grown in $\mathrm{As}_{250}$ soil was $12 \%$. The decrease was only proved in old fronds. The effect of frond senescence on $5 \mathrm{mC}$ content was not statistically significant, but the trend, in terms of average $5 \mathrm{mC}$ content, was lower in old fronds.

\section{Pigment content, fluorescence, WP and GEP of As-} exposed $P$. cretica var. Albo-lineata

Growth in $\mathrm{As}_{100}$ and $\mathrm{As}_{250}$ soil resulted in a decrease of chlorophyll contents (Chl A, Chl B and $\Sigma \mathrm{Chl}$ ) of $\mathrm{Pc}$-Al (Table 2). The content of carotenoids (Crt) was reduced by
As, but not significantly. Irrespective of the presence of added As in the soil, contents of all analysed pigments were higher in young fronds than in old fronds. Compared with controls, pigment content of ferns grown in the $\mathrm{As}_{100}$ soils was higher in young fronds, especially $\mathrm{Chl} \mathrm{A}$ and Crt contents (5-fold and 6-fold higher than those in old fronds, respectively). While the average value of $\mathrm{Chl} A$ and $\mathrm{Chl} B$ ratio remained unaffected by As in old fronds, it increased in young fronds of ferns grown in $\mathrm{As}_{100}$ soils (Table 2).

Chlorophyll fluorescence (Fv/Fm), as an indicator of plant photosynthetic activity, was lower in old fronds than in young fronds. The value of $\mathrm{Fv} / \mathrm{Fm}$ for young fronds from control plants $\left(0.82 \mu \mathrm{mol} \mathrm{m} \mathrm{m}^{-2} \mathrm{~s}^{-1}\right)$ responded to the quantum yield of photosystem II. During $\mathrm{As}_{100}$ stress Fv/ Fm of fronds decreased compared with controls (by $12.5 \%$ in young fronds and $14 \%$ in old fronds). Also $\mathrm{As}_{250}$ stress decreased Fv/Fm of old fronds - by 29\% (Table 2). The lowest value of $\mathrm{Fv} / \mathrm{Fm}$ (71\% of the value observed with the controls) was measured in $\mathrm{As}_{250}$ conditions in old fronds.

Table 1 Content of elements in young and old fronds of $P$. cretica var. Albo-lineata

\begin{tabular}{|c|c|c|c|c|c|}
\hline \multirow[t]{3}{*}{ Parameters } & \multicolumn{2}{|c|}{ Young fronds ( $\mathrm{mg} \mathrm{kg}^{-1}$ dry weight) } & \multicolumn{3}{|c|}{ Old fronds (mg kg ${ }^{-1}$ dry weight) } \\
\hline & control & $A s_{100}$ & control & $A s_{100}$ & $\mathrm{As}_{250}$ \\
\hline & $\bar{x} \pm S D$ & $\bar{x} \pm S D$ & $\bar{x} \pm S D$ & $\bar{x} \pm S D$ & $\bar{x} \pm S D$ \\
\hline As & $19 \pm 0.6^{\mathrm{aB}}$ & $2847 \pm 63^{\mathrm{bB}}$ & $12 \pm 0.1^{\mathrm{aA}}$ & $2034 \pm 47^{\mathrm{abA}}$ & $5056 \pm 143^{b}$ \\
\hline $\mathrm{Cu}$ & $5.1 \pm 0.1^{\mathrm{aA}}$ & $6.0 \pm 0.1^{\mathrm{bA}}$ & $5.5 \pm 0.1^{\mathrm{aB}}$ & $7.0 \pm 0.2^{\mathrm{abB}}$ & $11 \pm 0.2^{b}$ \\
\hline $\mathrm{Mg}$ & $2277 \pm 61^{\mathrm{bA}}$ & $2139 \pm 43^{\mathrm{aA}}$ & $2509 \pm 40^{\mathrm{aB}}$ & $3342 \pm 35^{\mathrm{abB}}$ & $4034 \pm 106^{b}$ \\
\hline $\mathrm{Mn}$ & $28 \pm 0.5^{\mathrm{bA}}$ & $23 \pm 0.9^{\mathrm{aA}}$ & $35 \pm 2^{\mathrm{aB}}$ & $52 \pm 1.3^{\mathrm{abB}}$ & $58 \pm 4^{\mathrm{b}}$ \\
\hline$S$ & $1326 \pm 27^{\mathrm{aA}}$ & $1372 \pm 43^{\mathrm{aA}}$ & $1521 \pm 51^{\mathrm{aB}}$ & $2195 \pm 17^{\mathrm{abB}}$ & $2420 \pm 179^{b}$ \\
\hline $\mathrm{Zn}$ & $17 \pm 0.2^{\mathrm{aA}}$ & $18 \pm 0.7^{\mathrm{aA}}$ & $21 \pm 0.4^{\mathrm{aB}}$ & $27 \pm 0.3^{\mathrm{abB}}$ & $39 \pm 1.2^{b}$ \\
\hline
\end{tabular}




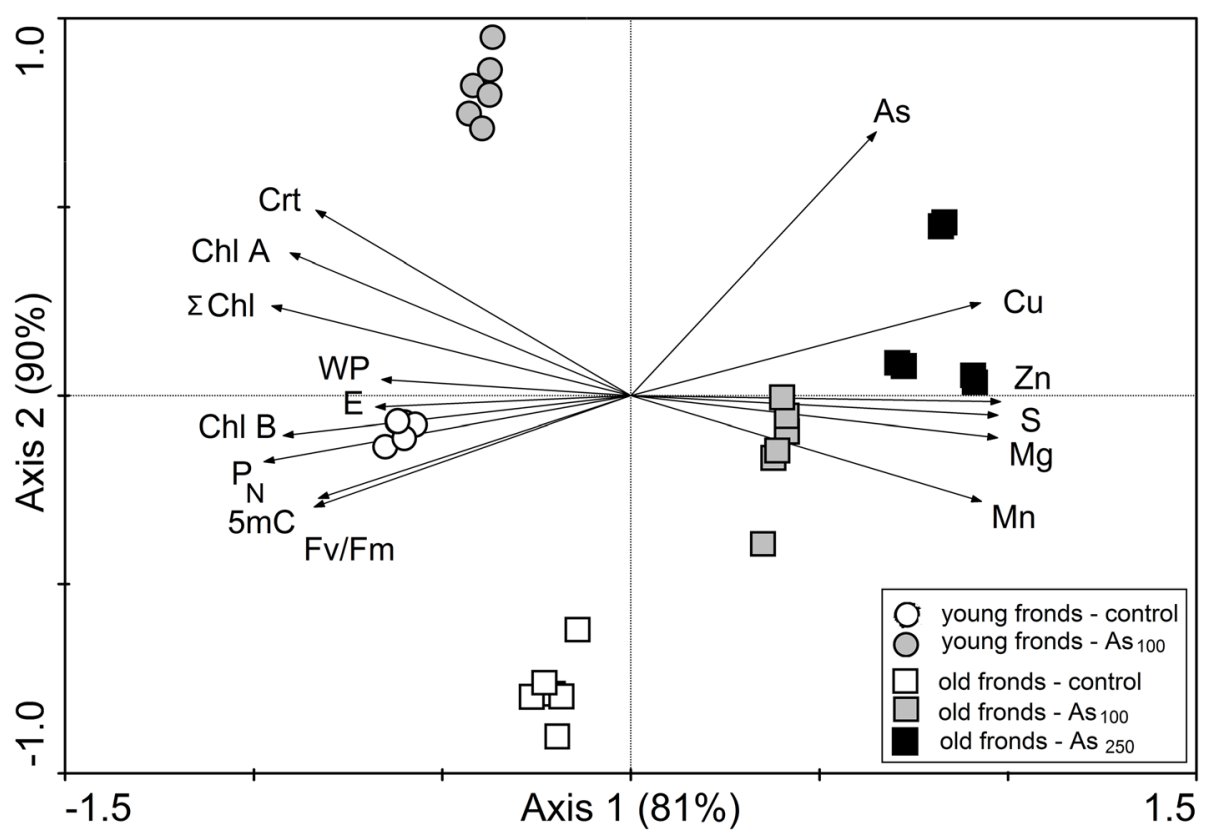

Fig. 2 Ordination diagram showing the results of PCA analysis with selected parameters in fronds of $P$. cretica var. Albo-lineata. Treatment abbreviations: control, treated with $0 \mathrm{mg} \mathrm{As} \mathrm{kg}^{-1}$ soil; $\mathrm{As}_{100}$, treated with $100 \mathrm{mg} \mathrm{As} \mathrm{kg}^{-1}$ soil; $\mathrm{As}_{250}$, treated with $250 \mathrm{mg} \mathrm{As} \mathrm{kg}^{-1}$ soil. Parameter abbreviations: Crt, carotenoids; Chl A, chlorophyll a; Chl B, chlorophyll b; $\Sigma$ Chl, total chlorophyll; WP, water potential; $\mathrm{P}_{\mathrm{N}}$, net photosynthetic rate; E, transpiration rate; Fv/Fm, fluorescence; 5mC, 5-methylcytosine; As, Cu, Mg, Mn, S and Zn; total content of elements

Observed declines in pigment content and $\mathrm{Fv} / \mathrm{Fm}$ in old leaves of fern in $\mathrm{As}_{100}$ and $\mathrm{As}_{250}$ soils indicated a faster progression of senescence.

Water potential (WP) was decreased in young and old fronds of the plants grown in $\mathrm{As}_{100}$ soil (by 36 and 118\%, respectively). Higher values of WP were observed in young fronds, irrespective of added As. To explore potential changes in roots, cross-section analysis through adventitious roots was performed. The roots of As treated plants showed thinning of the sclerenchymatous inner cortex and a reduction in average tracheid metaxylem in the vascular cylinder, compared to controls (Fig. 4).

From these data, the water-use efficiency was estimated $\left(\mathrm{WUE}=\mathrm{P}_{\mathrm{N}} / \mathrm{E}\right)$. Values with the same letter were not

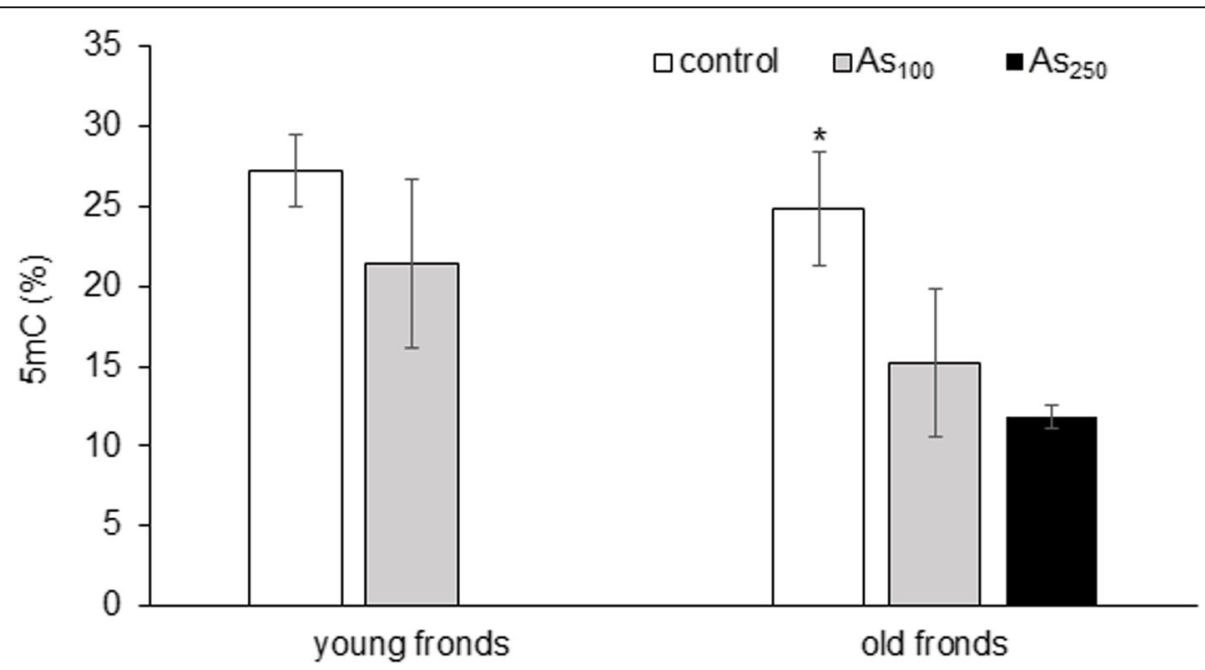

Fig. 3 Content of 5-methylcytosine $(5 \mathrm{mC})$ in young and old fronds of $P$. cretica var. Albo-lineata. Values represent mean \pm SD. The Kruskal-Wallis test was used to compare the significance $(p<0.05)$ between: i) treatments of young fronds (control and $\mathrm{As}_{100}$ ) and old fronds (control, As $s_{100}$ and $\mathrm{As}_{250}$ ) and ii) young and old fronds of control and $\mathrm{As}_{100}$ treatment. Treatments significantly different from each other are marked with asterisks. Differences between young and old frond was not significant. Coefficients of variation (CV, \%) are in Additional File 2 
Table 2 Physiological parameters in young and old fronds of P. cretica var. Albo-lineata

\begin{tabular}{|c|c|c|c|c|c|}
\hline \multirow[t]{3}{*}{ Parameters } & \multicolumn{2}{|l|}{ Young fronds } & \multicolumn{3}{|l|}{ Old fronds } \\
\hline & control & $\mathrm{As}_{100}$ & control & $\mathrm{As}_{100}$ & $\mathrm{As}_{250}$ \\
\hline & $\bar{x} \pm S D$ & $\bar{x} \pm S D$ & $\bar{x} \pm S D$ & $\bar{x} \pm S D$ & $\bar{x} \pm S D$ \\
\hline $\mathrm{Chl} \mathrm{A}\left(\mathrm{nmol} \mathrm{ml^{-1 }}\right)$ & $11 \pm 0.2^{\mathrm{bB}}$ & $10 \pm 0.5^{\mathrm{aB}}$ & $2.6 \pm 0.6^{\mathrm{bA}}$ & $1.5 \pm 0.4^{\mathrm{abA}}$ & $1.0 \pm 0.5^{\mathrm{a}}$ \\
\hline $\mathrm{Chl} \mathrm{B}\left(\mathrm{nmol} \mathrm{m} \mathbf{l}^{-1}\right)$ & $4.8 \pm 1.0^{\mathrm{bB}}$ & $2.8 \pm 0.2^{\mathrm{aB}}$ & $2.6 \pm 0.7^{\mathrm{bA}}$ & $1.9 \pm 0.4^{\mathrm{abA}}$ & $0.6 \pm 0.2^{\mathrm{a}}$ \\
\hline Chl A/Chl B (-) & $2.4 \pm 0.4^{\mathrm{aB}}$ & $3.6 \pm 0.03^{\mathrm{bB}}$ & $1.1 \pm 0.7^{\mathrm{aA}}$ & $0.9 \pm 0.5^{\mathrm{aA}}$ & $1.4 \pm 0.4^{\mathrm{a}}$ \\
\hline$\sum \mathrm{Chl}\left(\mathrm{nmol} \mathrm{ml}{ }^{-1}\right)$ & $16 \pm 1.0^{\mathrm{bB}}$ & $13 \pm 0.7^{\mathrm{aB}}$ & $5.2 \pm 0.1^{\mathrm{bA}}$ & $3.4 \pm 0.3^{\mathrm{abA}}$ & $1.6 \pm 0.7^{a}$ \\
\hline Crt $\left(\mathrm{nmol} \mathrm{m} \mathrm{l}^{-1}\right)$ & $2.4 \pm 0.1^{\mathrm{aB}}$ & $2.3 \pm 0.3^{\mathrm{aB}}$ & $0.5 \pm 0.2^{\mathrm{aA}}$ & $0.3 \pm 0.1^{\mathrm{aA}}$ & $0.3 \pm 0.04^{\mathrm{a}}$ \\
\hline $\mathrm{Fv} / \mathrm{Fm}\left(\mu \mathrm{mol} \mathrm{m} \mathrm{m}^{-2} \mathrm{~s}^{-1}\right)$ & $0.8 \pm 0.02^{\mathrm{bB}}$ & $0.7 \pm 0.03^{\mathrm{aB}}$ & $0.7 \pm 0.02^{\mathrm{bA}}$ & $0.6 \pm 0.07^{\mathrm{aA}}$ & $0.5 \pm 0.1^{\mathrm{a}}$ \\
\hline WP (MPa) & $-1.4 \pm 0.09^{\mathrm{aB}}$ & $-1.9 \pm 0.03^{\mathrm{bB}}$ & $-1.7 \pm 0.04^{\mathrm{aA}}$ & $-3.7 \pm 0.03^{\mathrm{bA}}$ & $-2.5 \pm 0.4^{\mathrm{ab}}$ \\
\hline $\mathrm{E}\left(\mathrm{mmol} \mathrm{H} \mathrm{H}_{2} \mathrm{O} \mathrm{m}^{-2} \mathrm{~s}^{-1}\right)$ & $0.7 \pm 0.2^{\mathrm{aA}}$ & $0.9 \pm 0.2^{\mathrm{bA}}$ & $0.8 \pm 0.1^{\mathrm{bA}}$ & $0.7 \pm 0.1^{\mathrm{aA}}$ & $0.3 \pm 0.04^{a}$ \\
\hline $\mathrm{P}_{\mathrm{N}}\left(\mu \mathrm{mol} \mathrm{CO}_{2} \mathrm{~m}^{-2} \mathrm{~s}^{-1}\right)$ & $8.1 \pm 0.1^{\mathrm{bB}}$ & $7.7 \pm 0.04^{\mathrm{aB}}$ & $7.7 \pm 0.04^{\mathrm{bA}}$ & $7.2 \pm 0.03^{\mathrm{abA}}$ & $6.7 \pm 0.1^{\mathrm{a}}$ \\
\hline WUE $(-)$ & $12 \pm 2.7^{\mathrm{bA}}$ & $8.6 \pm 1.3^{\mathrm{aA}}$ & $9.7 \pm 1.2^{\mathrm{aA}}$ & $9.4 \pm 0.6^{\mathrm{aA}}$ & $24.4 \pm 1.6^{b}$ \\
\hline
\end{tabular}

statistically significant at the 0.01 level by the KruskalWallis test. Different letters indicate significantly different values $(p<0.01)$ : a, b comparison between the treatments of young fronds (control and $\mathrm{As}_{100}$ ) and old fronds (control, $\mathrm{As}_{100}$ and $\left.\mathrm{As}_{250}\right) ; \mathrm{A}, \mathrm{B}$ comparison between young and old fronds for control and $\mathrm{As}_{100}$ treatment. Results for comparison between control and $\mathrm{As}_{100}$ of young and old fronds are in Additional File 1. Coefficients of variation $(\mathrm{CV}, \%)$ are in Additional File 2.

The $\mathrm{P}_{\mathrm{N}}$ and the rate of transpiration $(\mathrm{E})$ were determined to gain further insight into the photosynthetic performance in $P c$-Al fronds (Table 2). The $\mathrm{P}_{\mathrm{N}}$ and $\mathrm{E}$ data indicated a higher photosynthetic activity in the young fronds of the control ferns (Table 2, Fig. 2), and a decrease in the photosynthesis rate under As conditions (by $5 \%$ in young fronds and 13\% in old fronds). $28.5 \%$ increase of transpiration was observed in young fronds after As application. Compared with controls, added As decreased WUE only in young fronds (by 29\%).

\section{Principal component analysis of physiological parameters} The first axis of the PCA analysis explained $81 \%$ of the variability of all analysed data, the first two axes explained
$90 \%$ of the variability, and the first four axes together explained $99 \%$ of the variability. Diagramming PCA analysis was used for visualisation of all relationships between $P c$ $\mathrm{Al}$ parameters (Fig. 2; data only for $\mathrm{As}_{100}$ are in Additional File 3). In the PCA diagram, the first ordination axis divided the young fronds group on the left side from old fronds on the right side. This division indicated a large effect of frond senescence on all studied parameters. For young and old fronds, marks for treatments (control, $\mathrm{As}_{100}$ ) were located in the different parts of the diagram, which indicated a high effect of the treatments on all the recorded data. As observed with primary data, PCA confirmed that the accumulation of $\mathrm{Cu}, \mathrm{S}, \mathrm{Zn}, \mathrm{Mg}$ and $\mathrm{Mn}$ was more pronounced in old fronds of $P_{C}$-Al grown in $\mathrm{As}_{100}$ and $\mathrm{As}_{250}$ soils and that Chl B, $\mathrm{P}_{\mathrm{N}}, \mathrm{WP}, \mathrm{E}, \mathrm{Fv} / \mathrm{Fm}$, as well as $5 \mathrm{mC}$ were higher in young fronds of control plants. Arsenic content was negatively correlated with relative $5 \mathrm{mC}$ content of DNA as the angle between the vectors for As and $5 \mathrm{mC}$ was $>90^{\circ}$. Relationships visualised in the PCA diagram were confirmed by linear correlations (Table 3). The results in Table 3 showed an effect of As and $5 \mathrm{mC}$ of all treatments on other measured parameters. Correlations of As effect and $5 \mathrm{mC}$ on other parameters

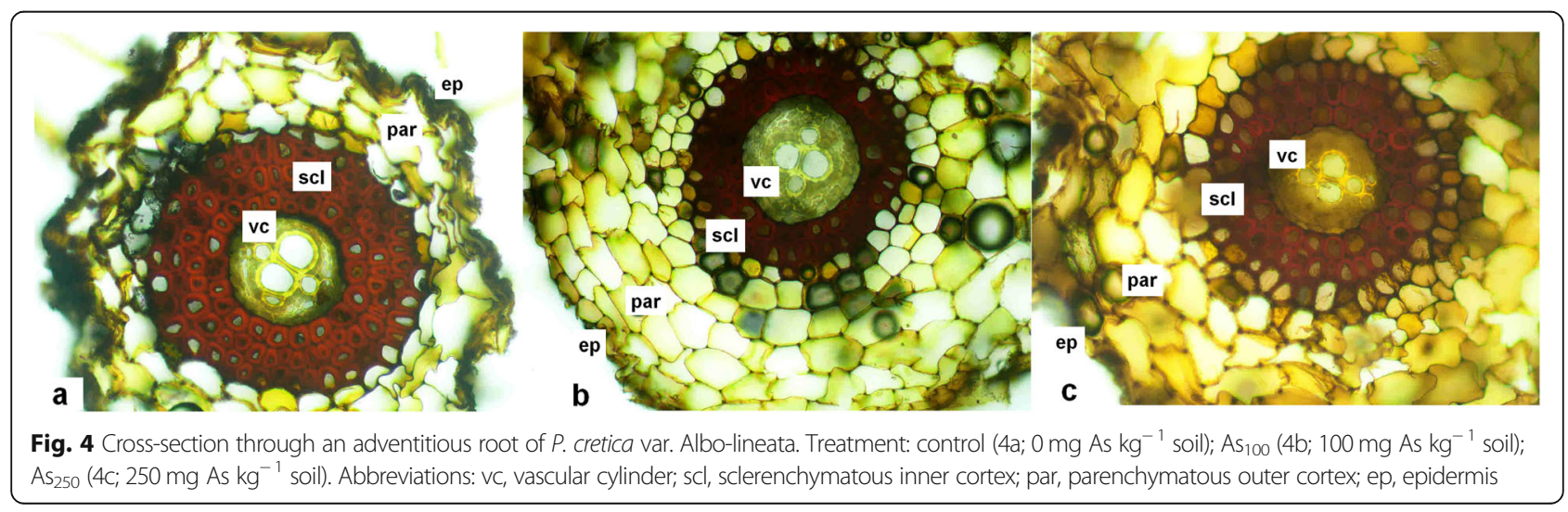


Table 3 Linear correlation of As and $5 \mathrm{mC}$ with selected parameters of $P$. cretica var. Albo-lineata

\begin{tabular}{|c|c|c|c|}
\hline As & $r$ & $5 \mathrm{mC}$ & $r$ \\
\hline $5 \mathrm{mC}$ & $-0.74^{* * *}$ & As & $-0.74^{* * *}$ \\
\hline $\mathrm{Mg}$ & $0.71^{* * *}$ & $\mathrm{Mg}$ & $-0.77^{* * *}$ \\
\hline $\mathrm{Cu}$ & $0.89^{* * *}$ & $\mathrm{Cu}$ & $-0.76^{* * *}$ \\
\hline $\mathrm{Zn}$ & $0.79^{* * *}$ & $\mathrm{Zn}$ & $-0.76^{* * *}$ \\
\hline$M n$ & $0.59^{* *}$ & $\mathrm{Mn}$ & $-0.74^{* * *}$ \\
\hline$S$ & $0.69^{* * *}$ & S & $-0.78^{* * *}$ \\
\hline $\mathrm{Chl} \mathrm{A}$ & $-0.38^{*}$ & $\mathrm{Chl} \mathrm{A}$ & $0.59^{* *}$ \\
\hline Chl B & $-0.75^{* * *}$ & Chl B & $0.69^{* * *}$ \\
\hline Crt & $-0.31^{\text {n.s. }}$ & Crt & $0.56^{* *}$ \\
\hline $\mathrm{Fv} / \mathrm{Fm}$ & $-0.77^{* * *}$ & $\mathrm{Fv} / \mathrm{Fm}$ & $0.74^{* * *}$ \\
\hline WP & $-0.41^{*}$ & WP & $0.64^{* * *}$ \\
\hline$E$ & $-0.56^{* * *}$ & E & $0.44^{*}$ \\
\hline$P_{N}$ & $-0.87^{* * *}$ & $\mathrm{P}_{\mathrm{N}}$ & $0.81^{* * *}$ \\
\hline
\end{tabular}

were calculated in different old fronds, where senescence was evaluated as a difference of tested parameters between young and old fronds (Table 3). The content of As in Pc$\mathrm{Al}$ fronds significantly correlated with $5 \mathrm{mC}$ and other physiological parameters, except Crt. Negative relationships of As were confirmed for pigments, Fv/Fm, WP, E and $\mathrm{P}_{\mathrm{N}}$. By comparison, these parameters were positively correlated with $5 \mathrm{mC}$. Negative relationships were found between $5 \mathrm{mC}$ and $\mathrm{Cu}, \mathrm{Mg}, \mathrm{Mn}, \mathrm{S}$ and $\mathrm{Zn}$. By comparison, these parameters were positively correlated with As. The effect of $\mathrm{As}$ and $5 \mathrm{mC}$ of low As treatment $\left(\mathrm{As}_{100}\right)$ is showed in Additional File 4.

\section{Discussion}

Our results show that when grown in chernozem soils spiked with 100 and $250 \mathrm{mg} \mathrm{As} \mathrm{kg}{ }^{-1}$, As could accumulate in the fronds of $P$. cretica var. Albo-lineata to >

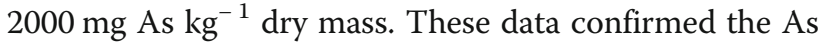
hyperaccumulation status of $P c-\mathrm{Al}$ and were consistent with results reported by Zhao et al. [3] for this fern and by $\mathrm{Tu}$ and $\mathrm{Ma}$ [5] for P. vittata. The As content in young fronds of control and $\mathrm{As}_{100}$ variants was higher than in old fronds. Effect of the development stage of fronds on As content was determined in Pteris umbrosa by Koller et al. [6]. During maturation of young fronds and senescence, As concentration in P. umbrosa exposed to 100 and $600 \mathrm{mg} \mathrm{As} \mathrm{L}^{-1}$ declined. This finding is consistent with our results for control and $\mathrm{As}_{100}$ variants.

Arsenic stress induces epigenetic changes in organisms, resulting in a decrease or increase in DNA methylation [19]. Analysis of $5 \mathrm{mC}$ in Pc-Al showed that As reduced the extent of DNA methylation. Similar results for heavy metals were published by Aina et al. [20]. The first paper focused on the effect of As on DNA methylation in plants was published by Erturk et al. [21]. Their results showed DNA hypermethylation of some genes in germinating maize seeds exposed to low As levels.

An increase of DNA methylation increases plant growth and transcriptionally represses genes involved in flavonoid biosynthesis [22]. A decrease of DNA methylation reduces plant growth and stimulates flowering, formation and growth of buds [13, 23, 24]. This finding was confirmed by our results. Dry biomass of $P c-\mathrm{Al}$ young fronds was decreased by $43 \%$ (Fig. 1). As revealed by PCA analysis (Fig. 2), physiological parameters of the plant are affected more strongly by the methylation status of $P c-\mathrm{Al}$ DNA than by direct As toxicity.

Some publications suggest that parts of DNA are sensitive to epigenetic changes [25]. However, in plants, the conservative parts of DNA without changes in DNA methylation were observed. Little information about the epigenetic activation of transcription of silenced plant genes of primary and secondary metabolites is known. Cazzonelli [26] described epigenetic changes linked to the regulation of metabolic pathways leading to carotenoid biosynthesis in relation to abscisic acid (control of carotenogenesis). According to Zhang et al. [27] epigenetic changes are linked with the biosynthesis of chlorophylls and tocopherols whose precursor is phytyl diphosphate. Lushchak and Semchuk [28] were also interested in these epigenetic changes. According to these authors, plants can increase photosynthesis by chlorophylls biosynthesis or by synthesizing the antioxidant metabolites tocopherols. We showed the continuity of changes in methylation/demethylation of cytosine DNA in relation to the photosynthetic pigments carotenoids and chlorophylls (primary relationship) and also to gasexchange parameters (GEP) or to $\mathrm{Fv} / \mathrm{Fm}$, which are indicators of plant photosynthetic activity.

It has been well documented that stress-related senescence processes involve the degradation of photosynthetic pigments [9], accompanied by a reduction in photosynthetic efficiency. Our results indicated that excess As reduced the level of chlorophylls and affected photosynthetic processes in $\mathrm{Pc}$ - $\mathrm{Al}$ fronds (Fig. 2, Tables 2 and 3). Farooq et al. [29] reported that As decreased GEP and pigment content in Brassica napus and, according to Wang et al. [30] this toxic element significantly affected $\mathrm{Fv} / \mathrm{Fm}$ in $P$. vittata within 60 days of exposure. An association between epigenetic changes in old fronds, resulting from As stress, and a reduced chlorophyll content might be indicated by the correlation between $5 \mathrm{mC}$ and $\mathrm{Chl} \mathrm{A}$ and Chl B levels (Table 3). The decline in the levels of carotenoids and chlorophylls in young fronds of $\mathrm{As}_{100}$ treated plants was less than that seen in older fronds. A significant increase of the Chl A/Chl B ratio was confirmed for young fronds of $\mathrm{As}_{100}$ plants. These changes, together with the values of $\mathrm{P}_{\mathrm{N}}, \mathrm{E}$ and $\mathrm{Fv} / \mathrm{Fm}$, pointed to a senescence in $\mathrm{As}_{100}$ plants. 
During senescence, plant metabolites are remobilised from old leaves to young leaves after expression of genes typical for senescence [31]. We found that As toxicity slightly increased leaf senescence (Fig. 2, Tables 1, 2 and 3). The opposite correlations results for $5 \mathrm{mC}$, in contrast to direct As toxicity (Table 3), showed that decreases of chlorophylls, fluorescence and $\mathrm{P}_{\mathrm{N}}$ could be affected by epigenetic changes. Ay et al. [32] published similar conclusions for the effects of epigenetic changes on physiological processes in plants.

A decrease of $5 \mathrm{mC}$ content in As plants led to a significant negative correlation with increased amounts of $\mathrm{Cu}$, $\mathrm{Zn}$ and $\mathrm{Mn}$, cofactors of superoxide dismutases, and with $\mathrm{S}$, a key element in the biosynthesis of cysteine and methionine. Increased accumulation of tested elements could be affected by epigenetic changes as showed by the significant correlations for $5 \mathrm{mC}$ (Table 3). While there was an elevation in the concentrations of $\mathrm{Cu}, \mathrm{Mn}$, and $\mathrm{Zn}$, in $P$. vittata exposed to As contamination [5], in $P c-A l$ it was more pronounced in old fronds as compared to young ones. These authors observed a same trend as we did - higher Mg content in old fronds compared to young ones in $P$. vittata. It was reasonable to assume that these elements were significant as cofactors of antioxidative metalloenzymes [33-35] as a part of chlorophylls $(\mathrm{Mg})$, and as non-enzymatic antioxidants, protecting against As-induced stress. Increased concentrations of S can be linked to the accumulation of glutathione and phytochelatins involved in detoxification of cellular As in P. cretica var. Mayii [36]. Based on this, the observation that the concentration of $\mathrm{S}$ and $\mathrm{Zn}$ remained unaffected and the concentrations of $\mathrm{Mn}$ and $\mathrm{Mg}$ were reduced in young fronds of $P c-\mathrm{Al}$ grown in $\mathrm{As}_{100}$ soil was surprising. We hypothesised that changes in $\mathrm{Mn}$ and $\mathrm{Mg}$ content were linked with $\mathrm{N}$ metabolism.

Water consumption by ferns is directly proportional to As contamination. One of the causes of changes in water content in fronds is the lignification of the conducting tissues in the roots. We found very low WP values for $\mathrm{As}_{100}$ and $\mathrm{As}_{250}$ plants as a result of stress attributable to As contamination (Table 2). Induced stress in cell walls leads primarily to the lack of water in fronds and secondarily to osmotic stress, which is a limiting factor for the growth and development of these plants. Leaf senescence together with the effect of As resulted in lignification of conducting tissue (Fig. 4). Similar reports of WP reduction as a result of the lignification of conducting tissue in plants exposed to stress conditions were published by Hare and Cress [37] and Yamaguchi et al. [38]. If the photosynthetic membrane system is protected by flavonoids, ascorbate and tocopherols [28, 39-41], then cell walls are protected by lignin [38]. Reduced DNA methylation in $\mathrm{Pc}-\mathrm{Al}$ increases biosynthesis of sterols, tocopherols, flavonoids, isoflavonoids and lignins because these plant metabolites are epigenetically regulated by silencing genes [40, 42, 43]. Cross-sections through adventitious roots of $\mathrm{As}_{100}$ and $\mathrm{As}_{250}$ plants showed the deformation of root cell walls as a result of lignification (Fig. 4). Zanella et al. [44] observed morphological changes in tobacco roots growing in $\mathrm{As}$ and $\mathrm{Cd}$ contaminated solutions. They found increased cell wall thickness due to lignin over-deposition in the rhizodermal and external cortical parenchyma cells of the primary structure zone, which led to premature exodermis formation. Similar changes in root, lignification upon exposure to metals were confirmed by Piršelová et al. [45]. According to cited works, the lignification-induced cellular changes result in a reduction in water uptake by plants. This finding is in line with our results: changes in WP values and morphological changes in the roots. Reduction of water content and metabolites subsequently limits the ability of the plant to overcome As toxicity.

\section{Conclusions}

The results of this paper point to changes in the metabolism of the As-hyperaccumulator plant Pteris cretica var. Albo-lineata, on exposure to 100 and $250 \mathrm{mg} \mathrm{As} \mathrm{kg}^{-1}$ contamination. Compared with controls, ferns grown in the $\mathrm{As}_{100}$ soils increased As concentrations in young and old fronds, 150- and 170-fold, respectively. Ferns grown in the $\mathrm{As}_{250}$ soil increased As concentration 421-fold compared to control. Higher As content was found in the young fronds in comparison to old fronds of control and $\mathrm{As}_{100}$ treatments. Analysis of $5 \mathrm{mC}$ content showed that accumulation of As was associated with affected DNA methylation. The decrease of $5 \mathrm{mC}$ was confirmed in old fronds (from 25 to $15 \%$ and $12 \%$ in contrast to control). As revealed by PCA and correlations, physiological parameters of the Pteris cretica var. Albo-lineata are strongly affected by the methylation status of DNA and by direct As toxicity. Increased accumulation of tested nutrients $(\mathrm{Cu}$, $\mathrm{Mn}, \mathrm{Zn}, \mathrm{Mg}$ and S) or decreased chlorophylls, Fv/Fm, $\mathrm{P}_{\mathrm{N}}$ and WP could be affected by epigenetic changes as was showed by our results.

Accumulation of As in plants affected photosynthetic processes and the content of pigments in fronds. There was a decrease of chlorophylls ( $\Sigma \mathrm{Chl}$ by $69 \%$ ) and $\mathrm{Fv} / \mathrm{Fm}$ (by $29 \%$ ) in old fronds of As treatment, indicating a faster progression of senescence. These changes together with values of $P_{N}$ and $E$, indicated reversible senescence in As plants. Based on our determination of very low values for WP (from - 1.4 to - 3.7) and morphological changes in the roots (lignification of cell walls) we proposed that transport of assimilated metabolites between roots and fronds might be reduced.

\section{Methods}

Plant material and experimental design

Plants of Pteris cretica (L.) var. Albo-lineata $(P c-\mathrm{Al})$ were obtained from the garden centre Tulipa Praha (Czech 
Republic). Ferns at the 10-15 fronds stage were planted in $5 \mathrm{~L}$ pots (1 fern for pot) under greenhouse conditions (natural photoperiod; temperature $22-24{ }^{\circ} \mathrm{C}$; relative humidity approximately 60\%) for 122 days. Each pot contained $5 \mathrm{~kg}$ of haplic chernozem mixed with $0.5 \mathrm{~g} \mathrm{~N}, 0.16 \mathrm{~g}$ $\mathrm{P}$ and $0.4 \mathrm{~g} \mathrm{~K}$ per $1 \mathrm{~kg}$ of soil (supplemented as $\mathrm{NH}_{4} \mathrm{NO}_{3}$ and $\mathrm{K}_{2} \mathrm{HPO}_{4}$ ). The soil used in this experiment (Table 4) was collected from a non-polluted area in PragueSuchdol, Czech Republic (508 ' 8" N, 14 $22^{\prime} 43^{\prime \prime}$ E). Ferns were grown in this soil without As supplement (control) and with two As dose - $100 \mathrm{mg}$ As per $\mathrm{kg}$ soil $\left(\mathrm{As}_{100}\right)$ and $250 \mathrm{mg}$ As per $\mathrm{kg}$ soil $\left(\mathrm{As}_{250}\right)$. Arsenic was added as a solution of $\mathrm{Na}_{2} \mathrm{HAsO}_{4}$ and was thoroughly mixed with the soil; maturation period of spiked soil was ten days. Each treatment was replicated three times. Above-ground biomass of control and $\mathrm{As}_{100}$ variants were separated to young and old fronds. The young and old fronds were separated according to their location in plant habit and their size. The young fronds were located lower ground of fern and their area did not exceed to $5 \times 10 \mathrm{~cm}$. The larger fronds from full habit were indicated as old fronds. Growth of new fronds were not found at $\mathrm{As}_{250}$ variants and senescent fronds were indicate as old fronds. After being harvested, the fronds were treated as described below. Cross-sections through an adventitious root were inspected using a Nikon E 200 microscope equipped with DS camera head and the NIS-Elements application (Nikon Instruments, Inc., Melville, NY, USA).

\section{Determination of arsenic and other elements}

Fronds were oven-dried for three days at $40{ }^{\circ} \mathrm{C}$. Homogenised material $(0.5 \pm 0.05 \mathrm{~g})$ was digested with a mixture of $\mathrm{HNO}_{3}$ and $\mathrm{H}_{2} \mathrm{O}_{2}(4: 1, \mathrm{v} / \mathrm{v})$ in an Ethos 1 device (MLS $\mathrm{GmbH}$, Leutkirch im Allgäu, Germany). Contents of As, $\mathrm{Cu}, \mathrm{Mg}, \mathrm{Mn}$, and $\mathrm{Zn}$ were determined using inductively coupled plasma-optical emission spectrometry (ICP-OES; Agilent 720, Agilent Technologies Inc., Santa Clara, CA, USA). Certified reference material (CRM NIST 1573a Tomato leaves, Analytika ${ }^{\oplus}$, Czech Republic) was mineralized under the same conditions for quality assurance.

\section{Isolation of DNA and determination of relative DNA methylation status based on \% 5-methylcytosine}

The fronds were weighed, frozen in liquid nitrogen and stored at $-80^{\circ} \mathrm{C}$ prior to DNA methylation analysis. To isolate total DNA, the fronds (1 $\mathrm{g}$ fresh weight) were ground to a fine powder in liquid nitrogen by mortar and pestle. DNA was extracted from $100 \mathrm{mg}$ of powdered tissue using a NucleoSpin Plant II molecular kit (Macherey-Nagel GmbH \& Co. KG, Düren, Germany), as instructed in the user manual. The global DNA methylation status of DNA was determined using $100 \mathrm{ng}$ of isolated DNA and a MethylFlash Methylated DNA Quantification Kit (Fluorometric; Epigentek Group Inc., Farmingdale, NY, USA) according to the manufacturer's instructions. A SpectraMax MiniMax 300 Imaging Cytometer (Molecular Devices LLC, San Jose, CA, USA) with excitation at $530 \mathrm{~nm}$ was used to measure the fluorescence at $590 \mathrm{~nm}$.

\section{Determination of pigments}

Pigment content in the leaves was measured photometrically with an Evolution 2000 UV-Vis (Thermo Fisher Scientific Inc., Waltham, MA, USA). A vessel-free leaf segment $\left(0.5 \mathrm{~cm}^{2}\right)$ excised from a freshly separated frond was incubated in the dark in $1 \mathrm{ml}$ dimethylformamide with shaking for $24 \mathrm{~h}$. The absorbance of the extract was measured at wavelengths 480, 646.8, and $663.8 \mathrm{~nm}$. Absorbance values at $710 \mathrm{~nm}$ were subtracted from these measurements. Data pigment contents were calculated from these data:

Chlorophyll A (Chl A; nmol ml-1): Chl A=12.0×

$\mathrm{A}_{663.8}-3.11 \times \mathrm{A}_{646.8}$.

Chlorophyll B: (Chl B; nmol ml-1): Chl B=20.78× $\mathrm{A}_{646.8}-4.88 \times \mathrm{A}_{663.8}$.

Total chlorophyll $\left(\Sigma \mathrm{Chl}\right.$; nmol ml $\left.\mathrm{ml}^{-1}\right): \mathrm{Chl} \mathrm{A}+\mathrm{Chl} \mathrm{B}=$ $7.12 \times \mathrm{A}_{663.8}+17.67 \times \mathrm{A}_{646.8}$.

Carotenoids (Crt; nmol ml $\left.{ }^{-1}\right): \mathrm{Crt}_{\mathrm{x}+\mathrm{c}}=\left(1000 \times \mathrm{A}_{480^{-}}\right.$ 1.12 Chl A - 34.07 Chl B) / 245.

\section{Determination of fluorescence}

The chlorophyll fluorescence [variable fluorescence (Fv)/

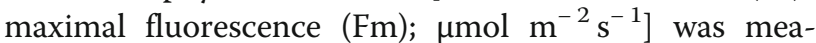
sured using a modulated chlorophyll fluorometer OS1FL (Opti-Sciences, ADC, BioScientific, Ltd., Hoddesdon, UK). The fresh leaf was obscured by clipping after 20 min to set up a dark-adapted state. Chlorophyll fluorescence was excited by a $660 \mathrm{~nm}$ solid-state light source, with filters blocking radiation longer than $690 \mathrm{~nm}$. Saturation of the photosystem being measured was achieved by using a filtered $35 \mathrm{~W}$ halogen lamp (350-690 nm) with a pulse of $15,000 \mu \mathrm{mol} \mathrm{m} \mathrm{s}^{-2} \mathrm{~s}^{-1}$ during $0.8 \mathrm{~s}$.

\section{Determination of water potential}

Water potential (WP; MPa), a measure of the energy status of the water in a system, was measured using a dew point PotentiaMeter (Decagon Devices, Inc., Pullman,

Table 4 Basic properties of soil

\begin{tabular}{|c|c|c|c|c|c|c|c|c|}
\hline $\begin{array}{l}\mathrm{pH}_{\mathrm{KCl}} \\
(-)\end{array}$ & $\begin{array}{l}\text { Corg } \\
(\%)\end{array}$ & $\begin{array}{l}\text { CEC } \\
\left(\mathrm{mmol}_{+} \mathrm{kg}^{-1}\right)\end{array}$ & $\begin{array}{l}\text { Total As } \\
\left(\mathrm{mg} \mathrm{kg}^{-1}\right)\end{array}$ & $\begin{array}{l}\text { Water extractable As } \\
\left(\mathrm{mg} \mathrm{kg}^{-1}\right)\end{array}$ & $\begin{array}{l}\text { Sand } \\
(\%)\end{array}$ & $\begin{array}{l}\text { Silt } \\
(\%)\end{array}$ & $\begin{array}{l}\text { Clay } \\
(\%)\end{array}$ & $\begin{array}{l}\text { Bulk density } \\
\left(\mathrm{g} \mathrm{cm}^{-3}\right)\end{array}$ \\
\hline 7.1 & 1.83 & 258 & $16 \pm 1.7$ & $0.10 \pm 0.01$ & 26 & 72 & 2 & 2.57 \\
\hline
\end{tabular}

$\mathrm{C}_{\text {org }}$ organic carbon; $\mathrm{CEC}$, cation exchange capacity. 
WA, USA). The leaves of the plants were placed in a disposable syringe, the air was drawn off from the syringe, and the syringe was tightly closed with parafilm. The specimen was frozen at $-18{ }^{\circ} \mathrm{C}$, then thawed, and the sap flow was pushed out into the measuring chamber of the PotentiaMeter.

\section{Determination of selected photosynthesis parameters with gas-exchange parameters (GEP)}

The net photosynthetic rate $\left(\mathrm{P}_{\mathrm{N}} ; \mu \mathrm{mol} \mathrm{CO} \mathrm{CO}_{2} \mathrm{~m}^{-2} \mathrm{~s}^{-1}\right)$ and the rate of transpiration (E; $\mathrm{mmol} \mathrm{H}_{2} \mathrm{O} \mathrm{m} \mathrm{m}^{-2} \mathrm{~s}^{-1}$ ) were determined with the portable gas exchange system LCpro+ (ADC BioScientific, Ltd., Hoddesdon, UK). The water-use efficiency parameter (WUE) was calculated from these determined values $\left(\mathrm{WUE}=\mathrm{P}_{\mathrm{N}} / \mathrm{E}\right)$. Values of $\mathrm{P}_{\mathrm{N}}$ and $\mathrm{E}$ were determined between 8:00 and 11:30 Central European Time (CET) and conditions of measurement chamber were described previously [46, 47].

\section{Statistical analysis}

All data were checked for homogeneity of variance and normality by Levene and Shapiro-Wilk tests. Collected data did not meet the conditions for the use of analysis of variance (ANOVA) and were thus evaluated by nonparametric Kruskal-Wallis test in the Statistica 12.0 program (StatSoft, Inc., Tulsa, OK, USA). Significant differences were assessed as effect of i) treatment on physiological parameters and ii) age of fronds on physiological parameters. A principal component analysis (PCA), in the CANOCO 4.5 program, was applied to all collected data as a single set. We used standardisation of species because data of different characters were analysed together. PCA was used to draw correlations from the complex data set. The results were visualised in the form of bi-plot ordination diagrams using the CanoDraw program [48]. Correlations were confirmed using a linear correlation ( $\mathrm{r}, p<$ $0.05, p<0.01, p<0.001)$ by Statistica 12.0.

\section{Supplementary information}

Supplementary information accompanies this paper at https://doi.org/10. 1186/s12870-020-2325-6.

Additional file 1. Table S1. Content of elements and physiological parameters in young and old fronds of $P$. cretica var. Albo-lineata growing on low As dose - As 100 .

Additional file 2. Table S2. Coefficients of variation (CV, \%) for the content of elements, DNA methylation and physiological parameters in $P$. cretica var. Albo-lineata.

Additional file 3. Figure S1. Ordination diagram showing the results of PCA analysis with selected parameters in fronds of $P$. cretica var. Albolineata growing on low As dose - As 100 Treatment abbreviations: control, treated with $0 \mathrm{mg} \mathrm{As} \mathrm{kg}^{-1}$ soil; $\mathrm{As}_{100}$, treated with $100 \mathrm{mg} \mathrm{As} \mathrm{kg}^{-1}$ soil. Parameter abbreviations: Crt, carotenoids; Chl A, chlorophyll a; Chl B, chlorophyll b; $\Sigma$ Chl, total chlorophyll; WP, water potential; $\mathrm{P}_{\mathrm{N}}$, net photosynthetic rate; $\mathrm{E}$, transpiration rate; $\mathrm{Fv} / \mathrm{Fm}$, fluorescence; $5 \mathrm{mC}$, 5-

methylcytosine; $\mathrm{As}, \mathrm{Cu}, \mathrm{Mg}, \mathrm{Mn}, \mathrm{S}$ and $\mathrm{Zn}$; total content of elements. The first axis of the PCA analysis explained $74 \%$ of the variability of all analysed data, the first two axes explained $94 \%$ of the variability, and the first four axes together explained $99 \%$ of the variability.

Additional file 4. Table S3. Linear correlation of As and $5 \mathrm{mC}$ with selected parameters of $P$. cretica var. Albo-lineata growing on low As dose $-\mathrm{As}_{100}$.

\section{Abbreviations}

5mC: 5-methylcytosine content; $\mathrm{As}_{100}$ : Treatment with $100 \mathrm{mg}$ As per kg soil; $\mathrm{As}_{250}$ : Treatment with $250 \mathrm{mg}$ As per kg soil; Chl A: Chlorophyll A; Chl B: Chlorophyll B; Crt: Carotenoids; E: Rate of transpiration; Fv/ Fm: Chlorophyll fluorescence; GEP: Gas-exchange parameters; PCA: Principal Component Analysis; PC-Al: Pteris cretica var. Albo-lineata; $P_{\mathrm{N}}$ : Net photosynthetic rate; WP: Water potential; WUE: Water-use efficiency

\section{Acknowledgements}

We thank Ms. Hana Zámečníková, from the Czech University of Life Sciences Prague, for analyses of arsenic and other elements.

\section{Authors' contributions}

MP and DP conceived and designed the experiments. MP and VZ calculated the relative DNA methylation status. FH calculated selected photosynthesis parameters. JČ performed cross-sections through the roots. VZ, DP, PK, MP analysed the data and wrote the paper. All authors have read and approved the final version of the manuscript.

\section{Funding}

This research was supported by the Czech Science Foundation, Grant No. 17$10591 \mathrm{~S}$ and by the Ministry of Education, Youth and Sports from European Regional Development Fund-Project "Centre for the investigation of synthesis and transformation of nutritional substances in the food chain in interaction with potentially harmful substances of anthropogenic origin: comprehensive assessment of soil contamination risks for the quality of agricultural production" [grant number CZ.02.1.01/0.0/0.0/16_019/0000845]. The funding bodies provided the financial support to the research projects, but did not involve in study design, data collection, analysis, or preparation of the manuscript.

\section{Availability of data and materials}

The datasets used and/or analysed during the current study available from the corresponding author on reasonable request. The plant material was bought from the Tulipa Praha garden centre (Czech Republic). No other permissions were necessary to buy and to cultivate these plants.

Ethics approval and consent to participate

Not applicable.

Consent for publication

Not applicable.

\section{Competing interests}

The authors declare that they have no competing interests.

\section{Author details}

${ }^{1}$ Isotope Laboratory, Institute of Experimental Botany, The Czech Academy of Sciences, Vídeňská 1083, 14220 Prague, Czech Republic. ${ }^{2}$ Department of Agro-Environmental Chemistry and Plant Nutrition, Faculty of Agrobiology, Food and Natural Resources, Czech University of Life Sciences Prague, Kamýcká 129, 16500 Prague, Czech Republic. ${ }^{3}$ Department of Biochemistry and Microbiology, University of Chemistry and Technology, Technická 5, 16628 Prague, Czech Republic. ${ }^{4}$ Department of Botany and Plant Physiology, Faculty of Agrobiology, Food and Natural Resources, Czech University of Life Sciences Prague, Kamýcká 129, 16500 Prague, Czech Republic.

Received: 14 August 2019 Accepted: 28 February 2020

Published online: 30 March 2020

References

1. Eisler R. Eisler's encyclopedia of environmentally hazardous priority chemicals. Amsterdam: Elsevier; 2007. 
2. Ye WL, Wood BA, Stroud JL, Andralojc PJ, Raab A, McGrath SP, et al. Arsenic speciation in phloem and xylem exudates of castor bean. Plant Physiol. 2010;154(3):1505-13.

3. Zhao FJ, Dunham SJ, McGrath SP. Arsenic hyperaccumulation by different fern species. New Phytol. 2002;156(1):27-31.

4. Su YH, McGrath SP, Zhu YG, Zhao FJ. Highly efficient xylem transport of arsenite in the arsenic hyperaccumulator Pteris vittata. New Phytol. 2008;180(2):434-41.

5. Tu C, Ma LQ. Effects of arsenic on concentration and distribution of nutrients in the fronds of the arsenic hyperaccumulator Pteris vittata $L$ Environ Pollut. 2005;135(2):333-40.

6. Koller CE, Patrick JW, Rose RJ, Offler CE, MacFarlane GR. Pteris umbrosa R. Br. As an arsenic hyperaccumulator: accumulation, partitioning and comparison with the established as hyperaccumulator Pteris vittata. Chemosphere. 2007; 66(7):1256-63.

7. Abbas G, Murtaza B, Bibi I, Shahid M, Niazi NK, Khan Ml, et al. Arsenic uptake, toxicity, detoxification, and speciation in plants: physiological, biochemical, and molecular aspects. Int J Environ Res Public Health. 2018;15(1):59.

8. Agnihotri A, Seth CS. Exogenously applied nitrate improves the photosynthetic performance and nitrogen metabolism in tomato (Solanum lycopersicum L. cv Pusa Rohini) under arsenic (M) toxicity. Physiol Mol Biol Plants. 2016;22(3):341-9.

9. Foyer $\mathrm{CH}$, Noctor $\mathrm{G}$. Redox regulation in photosynthetic organisms: signaling, acclimation, and practical implications. Antioxid Redox Signal. 2009;11(4):861-905.

10. Yaish MW. Editorial: epigenetic modifications associated with abiotic and biotic stresses in plants: an implication for understanding plant evolution. Front Plant Sci. 2017;8:1983.

11. Lechat MM, Brun G, Montiel G, Véronési C, Simier P, Thoiron S, et al. Seed response to strigolactone is controlled by abscisic acid-independent DNA methylation in the obligate root parasitic plant, Phelipanche ramosa L. Pomel J Exp Bot. 2015;66(11):3129-40

12. Bossdorf $\mathrm{O}$, Arcuri D, Richards $\mathrm{CL}$, Pigliucci M. Experimental alteration of DNA methylation affects the phenotypic plasticity of ecologically relevant traits in Arabidopsis thaliana. Evol Ecol. 2010;24(3):541-53.

13. Iwase Y, Shiraya T, Takeno K. Flowering and dwarfism induced by DNA demethylation in Pharbitis nil. Physiol Plant. 2010;139(1):118-27.

14. Ba Q, Zhang G, Wang J, Niu N, Ma S, Wang J. Gene expression and DNA methylation alterations in chemically induced male sterility anthers in wheat (Triticum aestivum L.). Acta Physiol Plant. 2014;36(2):503-12.

15. Bona E, Cattaneo C, Cesaro P, Marsano F, Lingua G, Cavaletto M, et al. Proteomic analysis of Pteris vittata fronds: two arbuscular mycorrhizal fung differentially modulate protein expression under arsenic contamination. Proteomics. 2010;10(21):3811-34.

16. Campos NV, Araújo TO, Arcanjo-Silva S, Freitas-Silva L, Azevedo AA, NunesNesi A. Arsenic hyperaccumulation induces metabolic reprogramming in Pityrogramma calomelanos to reduce oxidative stress. Physiol Plant. 2016; 157(2):135-46

17. He S, Hu Y, Wang H, Wang H, Li Q. Effects of indole-3-acetic acid on arsenic uptake ad antioxidative enzymes in Pteris cretica var. nervosa and Pteris ensiformis. Int J Phytoremediat. 2017;19(3):231-8.

18. Nagajyoti PC, Lee KD, Sreekanth TVM. Heavy metals, occurrence and toxicity for plants: a review. Environ Chem Lett. 2010;8(3):199-216.

19. Ushijima T, Okochi-Takada E. Aberrant methylations in cancer cells: where do they come from? Cancer Sci. 2005;96(4):206-11.

20. Aina R, Sgorbati S, Santagostino A, Labra M, Ghiani A, Citterio S. Specific hypomethylation of DNA is induced by heavy metals in white clover and industrial hemp. Physiol Plant. 2004;121(3):472-80.

21. Erturk FA, Aydin M, Sigmaz B, Taspinar MS, Arslan E, Agar G, et al. Effects of $\mathrm{As}_{2} \mathrm{O}_{3}$ on DNA methylation, genomic instability, and LTR retrotransposon polymorphism in Zea mays. Environ Sci Pollut Res. 2015;22(23):18601-6.

22. Shen $\mathrm{H}, \mathrm{He} H, \mathrm{Li} J$, Chen W, Wang X, Guo L, et al. Genome-wide analysis of DNA methylation and gene expression changes in two Arabidopsis ecotypes and their reciprocal hybrids. Plant Cell. 2012;24(3):875-92.

23. Burn JE, Bagnall DJ, Metzger JD, Dennis ES, Peacock WJ. DNA methylation, vernalization, and the initiation of flowering. Proc Natl Acad Sci U S A. 1993; 90(1):287-91.

24. Albrechtová JTP, Ullmann J, Krekule J, Seidlová F. Effect of 5-azacytidine on growth pattern in Chenopodium rubrum. Plant Sci. 1994;96(1-2):211-5.

25. Arase $\mathrm{S}$, Kasai M, Kanazawa A. In planta assays involving epigenetically silenced genes reveal inhibition of cytosine methylation by genistein. Plant Methods. 2012;8:10.
26. Cazzonelli $\mathrm{Cl}$. Carotenoids in nature: insights from plants and beyond. Funct Plant Biol. 2011;38(11):833-47.

27. Zhang C, Zhang W, Ren G, Li D, Cahoon RE, Chen M, et al. Chlorophyll synthase under epigenetic surveillance is critical for vitamin $\mathrm{E}$ synthesis, and altered expression affects tocopherol levels in Arabidopsis. Plant Physiol. 2015;168(4):1503-11.

28. Lushchak VI, Semchuk NM. Tocopherol biosynthesis: chemistry, regulation and effects of environmental factors. Acta Physiol Plant. 2012;34(5):1607-28.

29. Faroog MA, Gill RA, Ali B, Wang J, Islam F, Ali S, et al. Subcellular distribution, modulation of antioxidant and stress-related genes response to arsenic in Brassica napus L. Ecotoxicology. 2016;25(2):350-66.

30. Wang HB, Xie F, Yao YZ, Zhao B, Xiao QQ, Pan YH, et al. The effects of arsenic and induced-phytoextraction methods on photosynthesis in Pteris species with different arsenic-accumulating abilities. Environ Exp Bot. 2012;75:298-306.

31. Gaufichon L, Reisdorf-Cren M, Rothstein SJ, Chardon F, Suzuki A. Biological functions of asparagine synthetase in plants. Plant Sci. 2010;179(3):141-53.

32. Ay N, Janack B, Humbeck K. Epigenetic control of plant senescence and linked processes. J Exp Bot. 2014;65(14):3875-87.

33. Cakmak I. Tansley review no. 111. Possible roles of zinc in protecting plant cells from damage by reactive oxygen species. New Phytol. 2000;146(2): 185-205.

34. Fernández-Ocaña A, Chaki M, Luque F, Gómez-Rodríguez MV, Carreras A, Valderrama $R$, et al. Functional analysis of superoxide dismutases (SODs) in sunflower under biotic and abiotic stress conditions. Identification of two new genes of mitochondrial Mn-SOD. J Plant Physiol. 2011;168(11):1303-8.

35. Zemanová V, Pavlík M, Pavlíková D. Cadmium toxicity induced contrasting patterns of concentrations of free sarcosine, specific amino acids and selected microelements in two Noccaea species. PLoS One. 2017;12(5):e0177963.

36. Raab A, Feldmann J, Meharg AA. The nature of arsenic-phytochelatin complexes in Holcus lanatus and Pteris cretica. Plant Physiol. 2004;134(3):1113-22.

37. Hare PD, Cress WA. Metabolic implications of stress-induced proline accumulation in plants. Plant Growth Regul. 1997;21(2):79-102.

38. Yamaguchi $\mathrm{M}$, Valliyodan $\mathrm{B}$, Zhang J, Lenoble $\mathrm{ME}$, Yu O, Rogers $\mathrm{EE}$, et al. Regulation of growth response to water stress in the soybean primary root. I. Proteomic analysis reveals region-specific regulation of phenylpropanoid metabolism and control of free iron in the elongation zone. Plant Cell Environ. 2010:33(2):223-43.

39. Smirnoff $N$. The function and metabolism of ascorbic acid in plants. Ann Bot. 1996;78(6):661-9.

40. Abbasi AR, Hajirezaei M, Hofius D, Sonnewald U, Voll LM. Specific roles of aand $\gamma$-tocopherol in abiotic stress responses of transgenic tobacco. Plant Physiol. 2007;143(4):1720-38.

41. Tang YL, Ren WW, Zhang L, Tang KX. Molecular cloning and characterization of gene coding for $\gamma$-tocopherol methyltransferase from lettuce (Lactuca sativa). Genet Mol Res. 2011;10(4):3204-12.

42. Anterola AM, Lewis NG. Trends in lignin modification: a comprehensive analysis of the effects of genetic manipulations/mutations on lignification and vascular integrity. Phytochemistry. 2002;61(3):221-94.

43. Gas-Pascual E, Simonovik B, Schaller H, Bach TJ. Inhibition of cycloartenol synthase (CAS) function in tobacco BY-2 cells. Lipids. 2015;50(8):761-72.

44. Zanella L, Fattorini L, Brunetti P, Roccotiello E, Cornara L, D'Angeli S, et al. Overexpression of AtPCS1 in tobacco increases arsenic and arsenic plus cadmium accumulation and detoxification. Planta. 2016;243(3):605-22.

45. Piršelová B, Kuna R, Libantová J, Moravčíková J, Matuš́ková I. Biochemical and physiological comparison of heavy metal-triggered defense responses in the monocot maize and dicot soybean roots. Mol Biol Rep. 2011;38(5):3437-46.

46. Zemanová V, Pavlík M, Pavlíková D, Hnilička F, Vondráčková S. Responses to cd stress in two Noccaea species (Noccaea praecox and Noccaea caerulescens) originating from two contaminated sites in Mežica, Slovenia and Redlschlag. Austria Arch Environ Contam Toxicol. 2016;70(3):464-74.

47. Holá D, Benešová M, Fischer L, Haisel D, Hnilička F, Hniličková H, et al. The disadvantages of being a hybrid during drought: a combined analysis of plant morphology, physiology and leaf proteome in maize. PLoS One. 2017; 12(4):e0176121.

48. ter Braak CJF, Šmilauer P. CANOCO reference manual and CanoDraw for windows user's guide: software for canonical community ordination (version 4.5). Ithaca: Microcomputer Power; 2002.

\section{Publisher's Note}

Springer Nature remains neutral with regard to jurisdictional claims in published maps and institutional affiliations. 